\title{
IKATAN SILANG POLIURETAN DARI METILEN -4,4' DIFENILDIISOSIANAT (4,4'-MDI), POLIETILEN GLIKOL 400 (PEG 400), DAN MINYAK BEKAS PENGGORENGAN
}

\author{
Prasetya dan Sri Hilma Siregar
}

Program Studi Kimia, Fakultas MIPA dan Kesehatan, Universitas Muhammadiyah Riau J1. KH. Ahmad Dahlan No. 88. Sukajadi. Pekanbaru e-mail korespondensi: prasetya.go@gmail.com

\begin{abstract}
ABSTRAK
Sintesis poliuretan telah dilakukan dengan menggunakan monomer 4,4'-MDI, PEG 400, dan minyak Bekas Penggorengan. Gugus fungsi karakteristik poliuretan, dan ikatan silang (derajat penggembungan), masing-masingnya dianalisis dengan spektofotometer FT-IR, beberapa pelarut (THF). Berdasarkan hasil penelitian diketahui serapan inframerah poliuretan hasil sintesis memiliki korelasi dengan serapan inframerah poliuretan standar. Hasil pengujian derajat penggembungan menunjukkan poliuretan hasil sintesis memiliki derajat penggembungan.
\end{abstract}

Kata kunci: Gugus fungsi, Ikatan silang, Poliuretan,

\section{PENDAHULUAN}

Sintesis poliuretan pada dasarnya merupakan suatu aplikasi dari reaksi polimerisasi kondensasi. Reaksi polimerisasi kondensasi merupakan reaksi antara dua reaktan dengan dua gugus fungsi yang berbeda menghasilkan satu produk utama. Poliuretan yang terbentuk dari hasil reaksi kondensasi memiliki gugus uretan (-NHCOO) dalam unit ulangnya. Gugus uretan terbentuk sebagai hasil reaksi antara gugus isosianat (-NCO-) dengan gugus hidroksil ($\mathrm{OH})$ (Rohaeti, 2004).

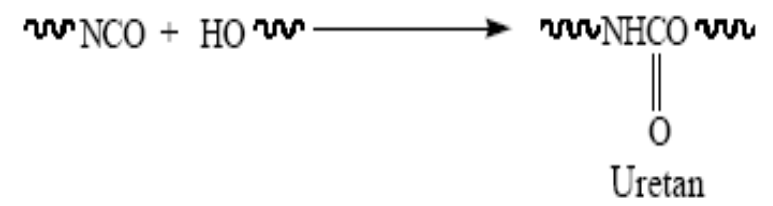

Poliuretan merupakan polimer serba guna karena memiliki sifat kimia-fisika yang beragam (tergantung kondisi saat sintesis). Poliuretan dapat bersifat elastis maupun kaku, relatif tahan terhadap goresan, cukup tahan terhadap panas, tidak larut dengan minyak, sehingga sangat aplikatif untuk dikembangkan dalam dunia industri diantaranya sebagai palapis dalam dunia otomotif, elektronik, kertas, busa, dan peralatan mekanik. Namun, di Indonesia, poliuretan masih harus diimpor, biaya produksi yang mahal, sehingga diharapkan melalui penelitian ini menghasilkan poliuretan dengan berbagai keunggulan dan sifat khas-nya (Prasetya, 2010).

Penelusuran literatur tentang penelitian sintesis poliuretan diketahui belum banyak. Adapun penelitian yang telah dilaporkan diantaranya yaitu Eli Rohaeti dan N.M. Surdia (2003) melakukan sintesis poliuratan dari MDI dan PEG dengan variasi berat molekul yaitu 200, 400, dan 1000 dengan modulus kelentingan untuk masingmasingnya 92,21; 8,96; dan 0,27 kPa. Sintesis poliuretan dari MDI, 1,4-Butanadiol, dan minyak kelapa yang dilakukan oleh Prasetya dan Pedy Artsanti (2010) dilaporkan memiliki suhu Tg dan Td masing-masingnya 266,38 
dan $537,22{ }^{\circ} \mathrm{C}$, serta tingkat kekerasan 79,83 Shore A.

Pada penelitian ini telah dilakukan sintesis poliuretan dari 4,4'-MDI: PEG 400: minyak Bekas Penggorengan dengan perbandingan 6: 3: 1 (b/b). Tujuan penelitian ini untuk mengetahui pengaruh perbedaan sumber hidroksil yang digunakan terhadap rapatan ikatan silang. Penelitian ini dilakukan berdasarkan hipotesis bahwa perbedaan sumber hidroksil memberikan konsekuensi logis terhadap derajat penggembungan, pada poliuretan hasil sintesis.

\section{METODOLOGI PENELITIAN}

Reaksi Polimerisasi Pembentukan

\section{Poliuretan}

Bahan-bahan yang digunakan dalam sintesis poliuretan ini adalah:

(i) Metilen-4,4'-difenildiisosianat (4,4'-MDI) berupa cairan kental berwarna coklat dengan rumus struktur sebagai berikut:

OCN

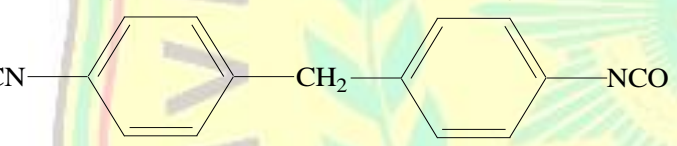

(ii) Polietilen glikol 400 (PEG 400) berupa cairan bening dengan rumus struktur sebagai berikut:

$$
\mathrm{HO}-\left(\mathrm{CH}_{2}-\mathrm{CH}_{2} \mathrm{O}\right)_{n}-\mathrm{H}
$$

(iii) Minyak Bekas Penggorengan yang mengandung asam lemak bebas

Pada penelitian ini dilakukan sintesis poliuretan dari monomer diisosianat (4,4'MDI) dengan variasi jenis monomer hidroksil (PEG 400 dan minyak Bekas Penggorengan). Selanjutnya diamati pengaruh variasi sumber hidroksil terhadap rapatan ikatan silang.

Reaksi polimerisasi pembentukan poliuretan dilakukan pada perbandingan berat 4,4'-MDI: PEG 400: Minyak bekas penggorengan masing-masing 6: $3: 1(\mathrm{~b} / \mathrm{b})$. Masing-masing monomer dimasukkan ke dalam dua reaktor. Selanjutnya dilakukan pengadukan campuran selama 60 detik dan sebelum dikarakterisasi, poliuretan hasil sintesis dimasukkan ke dalam oven dengan suhu $70^{\circ} \mathrm{C}$ selama 5 jam untuk menjalani proses curing.

\section{Karakterisasi Produk Polimerisasi}

Untuk melihat puncak serapan dari suatu gugus fungsi poliuretan hasil sintesis dilakukan dengan spektrofotometer FTIR. Sampel poliuretan yang telah berbentuk pelet dimasukkan ke ruang sampel. Kemudian diamati spektrum serapannya pada bilangan gelombang 400-4000 $\mathrm{cm}^{-1}$.

Derajat penggembungan diketahui berdasarkan ukuran derajat penggembungan polimer setelah poliuretan hasil sintesis di rendam pada tiga jenis pelarut berbeda yaitu tetrahidrofuran (THF), amilum $6,5 \%$, dan akuades.

\section{HASIL DAN PEMBAHASAN Spektrum FTIR}

Karaterisasi gugus fungsi dilakukan untuk mengetahui bahwa poliuretan telah terbentuk. Berdasarkan spektra inframerah, dapat diketahui gugus fungsi karakteristik poliuretan hasil sintesis dan dibandingkan dengan standar dari du Pont.

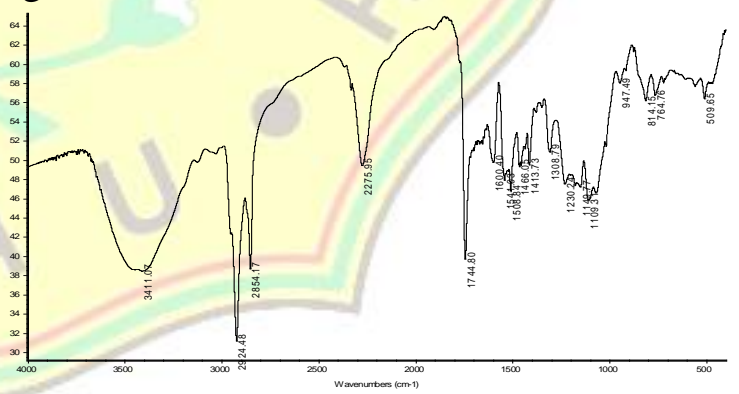

Gambar 1. Spektra Inframerah

Poliuretan dari 4,4'-MDI: PEG 400: Minyak

Bekas Penggorengan dengan Perbandingan

$$
6: 3: 1
$$

Spektra inframerah pada Gambar 1 . menunjukkan adanya serapan melebar pada $3411,07 \mathrm{~cm}^{-1}$ yang merupakan daerah ulur N$\mathrm{H}$ sekunder yang berikatan hidrogen. Puncak $\sim 2924,48 \mathrm{~cm}^{-1}$ merupakan daerah serapan 
ulur C-H alkana dan $3031,22 \mathrm{~cm}^{-1}$ daerah ulur C-H alkena. Serapan khas NCO dari 4,4'MDI ditunjukkan dengan puncak pada $2275,95 \mathrm{~cm}^{-1}$. Hal ini menunjukkan masih terdapat sisa MDI.

Daerah ulur $\mathrm{C}=\mathrm{O}$ uretan ditunjukkan oleh serapan pada $1744,80 \mathrm{~cm}^{-1}$. Terbentuknya gugus alofonat atau ikatan biuret pada poliuretan ditunjukkan oleh serapan dari uluran $\mathrm{C}=\mathrm{O}$ alofonat atau ikatan biuret pada $1413,73 \mathrm{~cm}^{-1}$. Puncak pada $1600,40 \mathrm{~cm}^{-1}$ menunjukkan serapan ulur $\mathrm{C}=\mathrm{O}$ urea dari hasil reaksi isosianat/berlebih dengan air atmosferik.

Adanya gugus aromatis ditunjukkan oleh serapan pada $1600,40 \mathrm{~cm}^{-1}$ dan $1508,84 \mathrm{~cm}^{-1}$ dan diperkuat dengan adanya puncak tunggal pada $814,15 \mathrm{~cm}^{-1}$ yang merupakan daerah serapan dari aromatik p-disubstitusi. Daerah serapan dari deformasi $\mathrm{N}-\mathrm{H}$ muncul pada bilangan gelombang $1541,03 \mathrm{~cm}^{-1}$. Serapan khas C-N-C ditunjukkan dengan munculnya puncak pada 1308,79 $\mathrm{cm}^{-1}$. Puncak 1109,31 $\mathrm{cm}^{-1}$ merupakan daerah serapan ulur C-O.

Jika spektra inframerah poliuretan hasil sintesis dibandingkan dengan daerah serapan standar poliuretan yang diproduksi du Pont, terdapat kesesuaian masing-masing serapan gugus fungsi kharakteristik. Jadi dapat diasumsikan poliuretan dapat dibentuk dari 4,4'-MDI: PEG 400: minyak Bekas Penggorengan dengan perbandingan 6:3:1 (w/w).

\section{Rapatan Ikatan Silang}

Analisis derajat penggembungan poliuretan yang disintesis dari 4,4'-MDI: PEG 400: minyak Bekas Penggorengan (6:3:1). pada ketiga pelarut THF, amilum 6,5 $\%$, dan akuades berturut-turut adalah 17,50\%, $29,41 \%$, dan $32,0 \%$. Kemampuan poliuretan untuk tidak larut dengan hadirnya pelarut disebabkan meningkatnya rapatan ikatan silang selama proses curing. Menurut Steven (2001), ikatan silang dapat terbentuk melalui reaksi antara gugus isosianat dengan gugus hidroksil membentuk ikatan silang uretan (Gambar 2) Pembentukan gugus uretan dibuktikan dengan serapan dari vibrasi ulur $\mathrm{C}=\mathrm{O}$ uretan pada spektra infra merah pada Gambar 1.

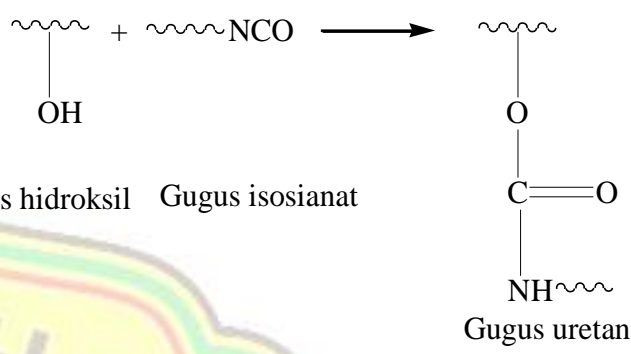

Gambar 2. Mekanisme Pembentukan Gugus Uretan

Steven (2001) juga menyatakan bahwa ikatan silang dapat terbentuk melalui reaksi lebih lanjut dengan diisosianat berlebih, yaitu suatu reaksi adisi yang melibatkan nitrogen dari ikatan uretan menghasilkan gugus alofonat (Gambar 3). Pembentukan gugus alofonat dibuktikan dengan serapan dari vibrasi ulur $\mathrm{C}=\mathrm{O}$ alofonat pada spektra inframerah pada Gambar 1.

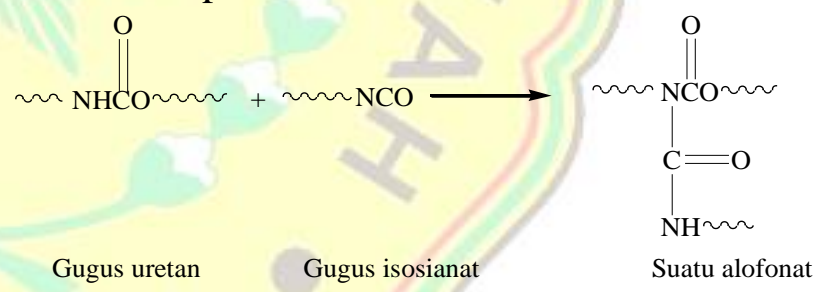

Gambar 3. Mekanisme Pembentukan Gugus Alofonat

Peningkatan rapatan ikatan silang menyebabkan meningkatnya massa molekul sehingga gaya tarik dalam rantai akan semakin kuat. Akibatnya, polimer tersebut semakin sulit ditembus pelarut dan akan memiliki derajat penggembungan yang rendah (Prasetya, 2010).

\section{KESIMPULAN}

Poliuretan dapat disintesis dari 4,4'-MDI: PEG 400: minyak Bekas Penggorengan pada 
perbandingan masing-masing 6:3:1 (w/w). Hasil pengujian derajat penggembungan ratarata dengan pelarut THF, amilum 6,5\%, dan akuades berturut-turut adalah 17,50\%, $29,41 \%$, dan $32,0 \%$. Hal ini menunjukkan bahwa didalam struktur poliuretan telah terbentuk ikatan silang.

\section{DAFTAR PUSTAKA}

Eli Rohaeti dan Sukisman Purtadi. 2004. Sintesis Poliuretan dari Propilen Glikol (PPG) dan Polifenil Isosianat (PAPI) sebagai Alternatif Sumber Belajar Kimia Material di SMA. Yogyakarta: Prosiding Seminar Nasional Kimia. FMIPA UNY.

Eli Rohaeti,dan N.M.Surdia. 2003. Pengaruh Variasi Berat Molekul Polietilen Glikol terhadap Sifat Mekanik Poliuretan.
http://www.fmipa.itb.ac.id/jms/file/JMS _VOL.\%208_NO.2_63-66.pdf.

Malcolm P. Stevens. 2001. Kimia Polimer. Jakarta: Pradnya Paramita.

Prasetya dan Pedy Artsanti. 2010. Sintesis dan Karakterisasi Poliuretan dari Metilen-4,4'- Difenildiisosianat (4,4'MDI): 1,4-Butanadiol: Minyak Kelapa. Prosiding Seminar Nasional Rekayasa Sains dan Teknologi 2010.

Prasetya dan Pedy Artsanti. 2010. Sintesis dan Karakterisasi Poliuretan dari Metilen-4,4'- Difenildiisosianat (4,4'MDI): Polietilen Glikol 400 (PEG 400): Minyak Kelapa. Prosiding Seminar Nasional MIPA Wilayah Barat (SEMIRATA) 2010. 